\title{
Personal protective equipment (PPE) for vitreoretinal surgery during COVID-19
}

\author{
Aman Chandra, ${ }^{1,2}$ Richard Haynes ${ }^{3} \cdot$ Michael Burdon $^{2,4} \cdot$ Alistair Laidlaw $^{5} \cdot$ James Neffendorf $^{5} \cdot$ lan Eames $^{6}$. \\ Lyndon daCruz ${ }^{7}$ Richard W. Lee ${ }^{8,9} \cdot$ Stephen Charles $^{10} \cdot$ Peter Wilson $^{11} \cdot$ Andrew Dick $_{(\mathbb{D}}{ }^{12,13,14} \cdot$ Declan Flanagan $^{2,7}$. \\ David Yorston $\mathbb{1}^{15} \cdot$ Melanie Hingorani ${ }^{2,7} \cdot$ Louisa Wickham ${ }^{2,7}$
}

Received: 26 April 2020 / Revised: 29 April 2020 / Accepted: 29 April 2020 / Published online: 12 May 2020

(c) The Royal College of Ophthalmologists 2020

SARS-CoV-2 is the recently discovered virus which has resulted in the pandemic illness known as coronavirus disease 2019 (COVID-19) [1]. It is from the family of viruses known as Coronaviridae, which were also responsible for severe acute respiratory syndrome (SARS), which originated in China in 2002, and Middle East respiratory syndrome coronavirus in 2012. It is thought to be a zoonosis, possibly originating in bats, which has undergone intraspecies transfer between intermediary hosts and humans.

The high infectivity of SARS-Cov-2 is a major contributor to this pandemic. Infectivity of a pathogen can be quantified as the basic reproduction number (R0). This is the number of cases directly generated by one case in a population where all individuals are susceptible to infection [2]. Estimates suggest that, for SARS-CoV-2, R0 is $>2.4$ [3-5]; thus for every case which occurs, on average more than two additional cases are generated in a susceptible population, in the absence of adequate measures such as isolation. For comparison, seasonal flu has an R0 of $\sim 1.2[6]$.

Aman Chandra

aman.chandra@southend.nhs.uk

1 Department of Ophthalmology, Southend University Hospital NHS Foundation Trust, Southend on Sea, UK

2 Royal College of Ophthalmologists, London, UK

3 Bristol Eye Hospital, Bristol, UK

4 Department of Ophthalmology, University Hospitals Birmingham NHS Foundation Trust, Birmingham, UK

5 Guys and St Thomas' Hospitals NHS Foundation Trust, London, UK

6 Department of Mechanical Engineering, University College London, London, UK

7 Moorfields Eye Hospital NHS Foundation Trust, London, UK
A major issue with regards to infectivity, particularly when considering implementing targeted measures to reduce spread, is the potential for transmission by asymptomatic patients. The risk of contagion presented by asymptomatic or mildly symptomatic cases of SARS-CoV-2 is unclear. The majority of descriptive papers investigating mild symptoms are focused on inpatients [7], specific populations [8] or modelling [9]. Although there are suggestions of lower infectivity amongst asymptomatic patients [9], this has not been confirmed. Estimates for the proportion of asymptomatic patients infected with SARS-CoV-2 in different populations range between 7 and $80 \%$ [10-12], with a substantial proportion of transmission occurring prior to illness onset [13, 14].

Protecting healthcare workers is an imperative [15], particularly for those who work in close proximity to patients' faces including ophthalmologists. Regularly updated recommendations have been issued to reduce patient contact and adjust patient flow for ophthalmology during the pandemic [16]. Gloves, disposable aprons, eye protection, fluid resistant type IIR surgical masks and slit

8 Department of Respiratory Medicine, Royal Marsden Hospital, London, UK

$9 \quad$ NHS Nightingale Hospital, London, UK

10 Manchester Royal Eye Hospital, Manchester, UK

11 Department of Microbiology, University College London Hospitals NHS Foundation Trust, London, UK

12 Translational Health Sciences, Bristol Medical School, University of Bristol, Bristol, UK

13 UCL Institute of Ophthalmology, London, UK

14 National Institute for Health Research Biomedical Research Centre at Moorfields Eye Hospital, London, UK

15 Gartnavel Hospital, Glasgow, UK 
lamp guards are recommended as personal protective equipment (PPE) for ophthalmic clinic assessment by the Royal College of Ophthalmologists [17]. In addition, the optimal type of respiratory protective masks remains a matter of important debate and varies. Within Europe, filtering face piece (FFP) respirator masks are graded based on filter efficacy and face adhesion: FFP 1-3 are able to filter with efficacies of $80 \%, 94 \%$ and $99 \%$ respectively $[14,18]$. Within the USA, FFP2 masks are termed N95. Guidelines for mask use vary worldwide. The European Centre for Disease and Prevention and the US CDC [19] recommend FFP2 masks (N95) for care of patients with COVID-19, whilst the WHO recommends standard surgical masks [20]. Within the UK, Public Health England regularly update their guidance with regard to PPE [21].

A major discriminator in determining mask use is whether staff are exposed to aerosols. SARS-CoV-2 likely binds in the first instance to nasal epithelial cells before migrating through the bronchial tree where it preferentially infects alveolar type II lung cells leading to a viral laden mucus that passes up the respiratory tract [22]. Transmission can occur through droplets and viral laden aerosols generated from breathing, coughing and sneezing and, in the healthcare environment, from procedures known as aerosol generating procedures. Large droplets are propelled through the air and can cause infection through a contact mechanism with or without fomites $[12,23]$. Small droplets may evaporate to create an aerosol; defined as small particles $(<10 \mu \mathrm{m}$ diameter) in suspension in gas [24]. Aerosols can remain suspended in the air for long periods, with the potential of travelling large distances (metres) transmitting disease by being inhaled and penetrating deeply into the respiratory tract. Symptomatic patients with SARS tend to develop lower respiratory tract infections, suggesting aerosol transmission is important [25]. Numerous studies have demonstrated the presence of influenza virus in exhaled breath $[26,27]$. SARS-CoV-2 has been demonstrated in tears [28], and causes ocular signs in patients with COVID-19 [29], although infrequently. Therefore, there is a potential for ocular mucosal transmission, though this is likely to be much less than via the respiratory mucosa. Viral presence in intraocular contents is unknown.

In AGPs, aerosols can be generated by applying sufficient mechanical energy (from high speed devices) to an airwater interface to form fine droplets. They can be generated from the evaporation of larger droplets $(<100 \mu \mathrm{m})$ as they settle in air and also by fragmentation of large droplets once they dry on surfaces and are later resuspended.

AGPs involving the upper respiratory tract including endotracheal intubation and airway suction are recognised to be associated with an increased risk of SARS transmission to healthcare workers [30] including SARS-CoV-2 [31] but the risks from other anatomical sites are less clear.
PHE has also included "surgery with high speed devices" as AGPs [21] There are reports of high speed drills and hydrosurgical debridement used in spinal surgery generating aerosols [32,33], and viable viral pathogen on dental drills [34]. Mask use in the context of AGP is more stringent. To try to avoid inhalation of small viral laden particles in the air requires a tight seal around the edge of the mask and greater filtering capacity. However, the exact requirements mandated vary throughout the world. Chinese physicians suggest that in addition to N95 masks, that "Full-face respiratory protective devices or powered air-purifying respirator" be employed [35]. In the UK, PHE recommends single use FFP masks [21].

There is, as yet, no robust evidence on the AGP nature of our intraocular surgical instruments. The frequency of modern phacoemulsification handpieces exceeds $40 \mathrm{kHz}$ and modern pars plana vitrectomy (PPV) handpieces have cut rates in excess of $5000 \mathrm{cuts} / \mathrm{min}$. These can therefore certainly be considered "high speed" surgical devices. In addition, it is possible that other vitreoretinal surgical manoeuvres could generate droplets or aerosol, such as fluid-air exchange. During the SARS-CoV-2 pandemic, it is likely that PPV for rhegmatogenous retinal detachment will be the most commonly performed intraocular surgery. The length of surgery in close proximity to patient airways poses further risk. To minimise risk of transmission, we as the Royal College of Ophthalmologists and the British and Eire Association of Vitreoretinal Surgeons have issued specific guidelines regarding these procedures [17]. These include reducing surgical volume, minimising staff presence and potential use of additional surgical drapes to minimise aerosol transmission. In particular, despite the absence of complete evidence at present, but based on the balance of risk and probability, we consider PPV should be treated as an AGP. We therefore advise appropriate PPE including FFP3 masks for surgeon and nurses during these procedures. Given the asymptomatic burden of SARS-Cov-2, we have recommended these precautions should be applied regardless of patients' symptoms [17]. We are pleased to note that the American Society of Retinal Specialists has more recently made similar recommendations [36] embodying a wider consensus. Recommendations will continue to adapt, reflecting the impact of social measures, new scientific evidence, more reliable viral testing and population healthcare needs.

The increased use of PPE worldwide is inevitably leading to supply shortages. Guidance from PHE continues to be updated in response to this issue, with advice now on reuse of gowns [37]. In the long term however there needs to be close coordination between medical, engineering, research and manufacturing communities to evaluate and extend the options for recycling and re-sterilising PPE on a large scale whilst maintaining 
anti-viral properties and protection. This needs to be undertaken multilaterally and urgently as the precious resource of PPE is shrinking.

The anxieties during this pandemic will not easily be allayed. However, by employing cautious clinical principles and ensuring high standard of protection, we hope to minimise the risk to surgeons, nurses and patients.

\section{Compliance with ethical standards}

Conflict of interest The authors declare that they have no conflict of interest.

Publisher's note Springer Nature remains neutral with regard to jurisdictional claims in published maps and institutional affiliations.

\section{References}

1. Ashour HM, Elkhatib WF, Rahman MM, Elshabrawy HA. Insights into the recent 2019 novel coronavirus (SARS-CoV-2) in light of past human coronavirus outbreaks. Pathogens. 2020;9. [Epub ahead of print]

2. Fraser C, Donnelly CA, Cauchemez S, Hanage WP, Van Kerkhove MD, Hollingsworth TD, et al. Pandemic potential of a strain of influenza A (H1N1): early findings. Science. 2009;324:1557-61.

3. Li Q, Guan X, Wu P, Wang X, Zhou L, Tong Y, et al. Early transmission dynamics in wuhan, china, of novel coronavirusinfected pneumonia. N Engl J Med. 2020;382:1199-207.

4. Zhang S, Diao M, Yu W, Pei L, Lin Z, Chen D. Estimation of the reproductive number of novel coronavirus (COVID-19) and the probable outbreak size on the Diamond Princess cruise ship: a data-driven analysis. Int J Infect Dis. 2020;93:201-4.

5. Liu Y, Gayle AA, Wilder-Smith A, Rocklov J. The reproductive number of COVID-19 is higher compared to SARS coronavirus. J Travel Med. 2020;27. [Epub ahead of print]

6. Biggerstaff M, Cauchemez S, Reed C, Gambhir M, Finelli L. Estimates of the reproduction number for seasonal, pandemic, and zoonotic influenza: a systematic review of the literature. BMC Infect Dis. 2014;14:480.

7. Liu Y, Yan LM, Wan L, Xiang TX, Le A, Liu JM et al. Viral dynamics in mild and severe cases of COVID-19. Lancet Infect Dis. 2020. [Epub ahead of print]

8. Mizumoto K, Kagaya K, Zarebski A, Chowell G. Estimating the asymptomatic proportion of coronavirus disease 2019 (COVID19) cases on board the Diamond Princess cruise ship, Yokohama, Japan, 2020. Euro Surveill. 2020;25. [Epub ahead of print]

9. Ferguson NM, Laydon D, Nedjati-Gilani G, Imai N, Ainslie K, Baguelin $\mathrm{M}$, et al. Impact of non-pharmaceutical interventions (NPIs) to reduce COVID-19 mortality and healthcare demand. http://www.imperial.ac.uk/media/imperial-college/medicine/sph/ ide/gida-fellowships/Imperial-College-COVID19-NPI-modelling16-03-2020.pdf. Accessed 7 Apr 2020.

10. Quilty BJ, Clifford S, Flasche S, Eggo RM, group Cnw. Effectiveness of airport screening at detecting travellers infected with novel coronavirus (2019-nCoV). Euro Surveill. 2020;25. [Epub ahead of print]

11. Nishiura H, Kobayashi T, Suzuki A, Jung SM, Hayashi K, Kinoshita R, et al. Estimation of the asymptomatic ratio of novel coronavirus infections (COVID-19). Int J Infect Dis. 2020;94: $154-5$.
12. WHO. Q\&A: similarities and differences-COVID-19 and influenza. https://www.who.int/emergencies/diseases/novel-corona virus-2019/question-and-answers-hub/q-a-detail/q-a-similarities-a nd-differences-covid-19-and-influenza.

13. Nishiura H, Linton NM, Akhmetzhanov AR. Serial interval of novel coronavirus (COVID-19) infections. Int J Infect Dis. 2020; 93:284-6.

14. Li C, Ji F, Wang L, Wang L, Hao J, Dai M et al. Asymptomatic and human-to-human transmission of SARS-CoV-2 in a 2 -family cluster, Xuzhou, China. Emerg Infect Dis. 2020;26. [Epub ahead of print]

15. The L. COVID-19: protecting health-care workers. Lancet. 2020; 395:922.

16. Romano MR, Montericcio A, Montalbano C, Raimondi R, Allegrini D, Ricciardelli G, et al. Facing COVID-19 in Ophthalmology department. Curr Eye Res. 2020:1-6. [Epub ahead of print]

17. Royal College of Ophthalmologists. Vitreoretinal Surgery During COVID-19 Pandemic (Royal College of Ophthalmologists. https://www.rcophth.ac.uk/wp-content/uploads/2020/04/ Vitreoretinal-surgery-management-guidance-070420-1.pdf.

18. Lee SA, Hwang DC, Li HY, Tsai CF, Chen CW, Chen JK. Particle size-selective assessment of protection of European standard FFP respirators and surgical masks against particlestested with human subjects. J Healthc Eng. 2016;2016. [Epub ahead of print]

19. CDC. Interim Infection Prevention and Control Recommendations for Patients with Suspected or Confirmed Coronavirus Disease 2019 (COVID-19) in Healthcare Settings. https://www.cdc.gov/ coronavirus/2019-ncov/hcp/infection-control-recommendations. html?. Accessed Apr 2020.

20. WHO. Rational use of personal protective equipment for coronavirus disease 2019 (COVID-19). https://apps.who.int/iris/ bitstream/handle/10665/331215/WHO-2019-nCov-IPCPPE_use2020.1-eng.pdf. Accessed Apr 2020.

21. Public Health England. Recommended PPE for healthcare workers by secondary care inpatient clinical setting, NHS and independent sector. https://assets.publishing.service.gov.uk/government/uploads/ system/uploads/attachment_data/file/877728/T1_Recommended_ PPE_for_healthcare_workers_by_secondary_care_clinical_ context_poster.pdf. Accessed 7 Apr 2020.

22. Mason RJ. Pathogenesis of COVID-19 from a cell biology perspective. Eur Respir J. 2020;55. [Epub ahead of print]

23. Tang JW, Li Y, Eames I, Chan PK, Ridgway GL. Factors involved in the aerosol transmission of infection and control of ventilation in healthcare premises. J Hosp Infect. 2006;64:100-14.

24. Tellier R, Li Y, Cowling BJ, Tang JW. Recognition of aerosol transmission of infectious agents: a commentary. BMC Infect Dis. 2019;19:101.

25. Peiris JS, Chu CM, Cheng VC, Chan KS, Hung IF, Poon LL, et al. Clinical progression and viral load in a community outbreak of coronavirus-associated SARS pneumonia: a prospective study. Lancet. 2003;361:1767-72.

26. Fabian P, McDevitt JJ, DeHaan WH, Fung RO, Cowling BJ, Chan $\mathrm{KH}$, et al. Influenza virus in human exhaled breath: an observational study. PLoS ONE. 2008;3:e2691.

27. Stelzer-Braid S, Oliver BG, Blazey AJ, Argent E, Newsome TP, Rawlinson WD, et al. Exhalation of respiratory viruses by breathing, coughing, and talking. J Med Virol. 2009;81:1674-9.

28. Xia J, Tong J, Liu M, Shen Y, Guo D. Evaluation of coronavirus in tears and conjunctival secretions of patients with SARS-CoV-2 infection. J Med Virol. 2020. [Epub ahead of print]

29. Wu P, Duan F, Luo C, Liu Q, Qu X, Liang L, et al. Characteristics of ocular findings of patients with coronavirus disease 2019 (COVID-19) in Hubei Province, China. JAMA Ophthalmol. 2020. [Epub ahead of print] 
30. Tran K, Cimon K, Severn M, Pessoa-Silva CL, Conly J. Aerosol generating procedures and risk of transmission of acute respiratory infections to healthcare workers: a systematic review. PLoS ONE. 2012;7:e35797.

31. van Doremalen N, Bushmaker T, Morris DH, Holbrook MG, Gamble A, Williamson BN, et al. Aerosol and Surface Stability of SARS-CoV-2 as compared with SARS-CoV-1. N Engl J Med. 2020;382:1564-7.

32. Nogler M, Lass-Florl C, Ogon M, Mayr E, Bach C, Wimmer C. Environmental and body contamination through aerosols produced by high-speed cutters in lumbar spine surgery. Spine. 2001;26:2156-9.

33. Putzer D, Lechner R, Coraca-Huber D, Mayr A, Nogler M, Thaler $\mathrm{M}$. The extent of environmental and body contamination through aerosols by hydro-surgical debridement in the lumbar spine. Arch Orthop Trauma Surg. 2017;137:743-7.

34. Epstein JB, Rea G, Sibau L, Sherlock CH, Le ND. Assessing viral retention and elimination in rotary dental instruments. J Am Dent Assoc. 1995;126:87-92.

35. First Affiliated Hospital. Handbook of COVID-19 Prevention and Treatment. http://www.alnap.org/help-library/handbook-of-covid19-prevention-and-treatment.

36. American Society of Retinal Specialists. http://www.asrs.org.

37. ENGLAND PH. Considerations for acute personal protective equipment (PPE) shortages. http://www.gov.uk/government/publica tions/wuhan-novel-coronavirus-infection-prevention-and-control/ managing-shortages-in-personal-protective-equipment-ppe-eyeprotection. Accessed Apr 2020. 